\title{
Emotional and Motivational Barriers to Effective Learning of Students
}

\begin{tabular}{ccc}
\hline Article Type & Received Date & Accepted Date \\
Research & 08.02 .2019 & 10.05 .2019 \\
\hline
\end{tabular}

\section{Eda Gürlen * Tuğba Cihan ** Nuri Doğan***}

\begin{abstract}
This study aims to determine and evaluate the learning barriers of high school students in Turkey. These barriers are examined from various emotional and motivational dimensions, such as selfefficacy, self-regulation, deficiency of professional/parental/sibling support and consultancy, learning environment, fear of failure, rejection, criticism and judgment and embarrassment. These dimensions in learning barriers influence all kinds of measurements to be carried on about students. Therefore, describing and revealing them may help handle the measurement outcomes gathered from students in different ways. The study employed a descriptive research methodology to collect data from all regions of Turkey. In this study, six scales were administered to the participants, who are 2175 high school students from the ninth, tenth and eleventh grades attending high schools. The results of the study suggest that students have some difficulty in planning how to study, which is a self-regulative skill. The participants' views mostly show that teacher support can make a strong learning barrier. Parental support is also another learning barrier. Furthermore, it was found out that the learning environment in classrooms did not motivate students to learn.
\end{abstract}

Keywords: learning barriers, emotional barriers, motivational barriers, effective learning, high school students.

\footnotetext{
* Assoc. Prof. Dr., Hacettepe University, Faculty of Education, Department of Curriculum and Instruction, Ankara, Turkey. E-mail: edaerdem@ hacettepe.edu.tr, https://orcid.org/0000-0002-1719-9840

${ }^{* *}$ Corresponding Author: Dr., Ankara University, School of Foreign Languges, Ankara, Turkey. E-mail: tugbagunes@gmail.com, https://orcid.org/0000-0002-6179-855X

**** Prof. Dr., Hacettepe University, Department of Educational Measurement and Evaluation, Ankara, Turkey.

E-mail: nurid@ @acettepe.edu.tr, https://orcid.org/0000-0001-6274-2016
} 


\title{
Öğrencilerin Etkili Öğrenmelerinde Duyuşsal ve Motivasyon Engelleri
}

\begin{tabular}{ccc}
\hline $\begin{array}{c}\text { Makale Türü } \\
\text { Araştırma }\end{array}$ & $\begin{array}{c}\text { Başvuru Tarihi } \\
08.02 .2019\end{array}$ & $\begin{array}{c}\text { Kabul Tarihi } \\
10.05 .2019\end{array}$ \\
\hline Eda Gürlen $^{*}$ & Tuğba Cihan & \\
& & Nuri Doğan $^{* * *}$ \\
& $\ddot{\mathbf{O z}}_{\mathbf{z}}$
\end{tabular}

\begin{abstract}
$\mathrm{Bu}$ çalışmanın amacı, Türkiye'deki lise öğrencilerinin karşılaştıkları öğrenme engellerini belirlemek ve değerlendirmektir. Söz konusu bu engeller, öz yeterlilik, öz düzenleme, profesyonel/ebeveyn/kardeş rehberlik desteğindeki eksiklik, öğrenme ortamı, başarısızlık, reddedilme, eleştiri ve yargılanma korkusu ve utanma gibi duyuşşal ve motivasyon boyutları açısından bu çalışmada değerlendirilmektedir. Öğrenme engellerindeki söz konusu boyutlar, öğrencilerle ilgili yürütülen tüm ölçme çalışmalarını doğrudan etkilemektedir. Bu nedenle, bahsedilen ögrenme engellerini betimlemenin ve ortaya çıarmanın, öğrencilerden alınan ölçme sonuçlarını değerlendirmede yardımcı olabileceği düşünülmektedir. Bu çalışmada araştırma deseni olarak, Türkiye'nin tüm bölgelerinden veri toplamak amaciyla betimsel yöntem kullanılmıştır. Veri toplama aracı olarak, geliştirilmiş olan altı öğrenme bariyeri ölçeği dokuzuncu, onuncu ve onbirinci sınıfa devam etmekte olan 2175 lise öğrencisine uygulanmıştır. Çalışmanın sonuçlarına göre, öğrenciler, bir öz düzenleme becerisi olan çalışmayı planlama becerisinde zorluk çekmektedirler. Ayrıca, katılımcıların yanıtları çoğunlukla öğretmen desteğinin güçlü bir öğrenme engeli olarak karşımıza çıkmaktığını göstermektedir. Ebeveyn desteğinin ise bir başka öğrenim engelini oluşturduğu görülmektedir. Ayrıca, çalışma sonuçlarına göre, sınıflardaki öğrenme ortamının öğrencileri öğrenmeye motive etmediği ortaya çıkmıştır.
\end{abstract}

Anahtar Sözcükler: öğrenme engelleri, duyuşsal engeller, motivasyonel engeller, etkili öğrenme, lise öğrencileri.

\footnotetext{
* Doç.Dr., Hacettepe Üniversitesi, Eğitim Fakültesi, Eğitim Programları ve Öğretim Anabilim Dalı, Ankara, Türkiye. E-posta: edaerdem@ hacettepe.edu.tr, https://orcid.org/0000-0002-1719-9840

** Sorumlu Yazar: Tuğba Cihan: Dr., Ankara Üniversitesi, Yabancı Diller Yüksekokulu, Ankara, Türkiye. E-posta: tugbagunes@gmail.com, https://orcid.org/0000-0002-6179-855X

*** Prof., Hacettepe Üniversitesi, Eğitim Fakültesi, Eğitimde Ölçme ve Değerlendirme Anabilim Dalı, Ankara, Türkiye. E-posta: nurid@hacettepe.edu.tr https://orcid.org/0000-0001-6274-2016
} 


\section{Introduction}

The concept of barriers to learning includes both external and internal factors that affect students' capabilities to receive educational instruction. These barriers to learning might result from a wide range of problems including restricted opportunities due to poverty, diverse family conditions, high rates of mobility, unfavorable neighborhood conditions or lack of enrichment opportunities (Adelman \&Taylor, 2008). Therefore, a great number of children cannot be successful in school due to dealing with a problematic family life, financial difficulties or emotional problems (Webb, Stewart, Bunting \&Regan, 2012). Sometimes determining perpetual barriers in the learner or the system and addressing these by enabling mechanisms and processes could be possible, but barriers might also appear during the learning process (NCESS, 1997). Nonetheless, "it needs to be stressed that few youngsters start out with internal problems that interferewith learning. That is why it is essential to view the continuum through the lens of barriers to learning and teaching with an appropriate appreciation of the full range of external factors that contribute to the majority of learning, behavior, and emotional problems encountered at school" (Adelman \& Taylor, 2008, p. 27).

Since there is a really wide range of barriers to learning as aforementioned, the present study focuses on barriers stemming from self- regulation skills; the level of self-efficacy; family conditions; studying environment; learning environment and factors related to peers, professional support as well as motivational and emotional factors, which all seem to be related to each other in one way or another. Self-regulated learning, which can be defined as an active process where students define their learning objectives, regulate their own learning and control their motivation (Zimmerman, 1986), is the key domain of learning and therefore, if there is a problem with this skill, it might become a significant barrier to learning (Osterholt \& Dennis, 2011). There is a strong relationship between selfregulation strategies and motivational beliefs and academic achievement (Young \& Vrongistinos, 2002). Studies conducted in recent decades indicate the significance of motivation for learning in students' adaptation to studying and capability to cope with difficulties and failure (Endler, Rey \& Butz, 2001).

There is evidence (Bandura, 1997) that self-efficient students take place in school work more readily, work harder without giving up for a longer time, and have fewer adverse emotional reactions when facing difficulties than those who are doubtful about their abilities as self-efficacy affect them emotionally and reduce their stress, anxiety and depression (as cited by Zimmerman, 2000; Ames, 1992). Self-efficacy beliefs let students have a feeling of agency to motivate their own learning by using goal setting, self-monitoring, self-evaluation, and strategy use that are mong self-regulatory skills (Zimmerman, 2000). Like the strong relationship among self-regulation, self-efficacy and motivational factors, contextual effects also have significant effects on student achievement, as studies show (Willms, 1999). Schools are likely to have higher levels of student engagement provided that there is a strong disciplinary climate, good relationships between student and teacher as well as high expectations for student achievement (OECD, 2003). Parent involvement can also help students feel more motivated to work hard and be more engaged with school work (López, 2001). This can be supported with the fact that many schools which try to cope with low academic achievement are reported to receive minimal parental involvement (Fuller \& Olsen, 1998). As for professional support, some evaluations about counselling services in UK secondary schools show that it is a powerful act (Adamson et al, 2006; Fox \& Butler, 2007/2009; McKenzie et al, 2011) and evidence also indicated that counselling promoted students' capacities to study and learn (as cited by Webb, Stewart, Bunting \&Regan, 2012).

In the Turkish context, limited research has been done regarding learning barriers in schools. Turhan, Karabatak and Polat (2014) conducted a study about the organizational learning barriers. The findings of the study indicated that teachers are inclined to limit their responsibility with their position and in the event of failure; they tend to accuse parents, families or students for the problem, are reluctant to take responsibility, expect the solution of their problems from the managers and are insensitive to problems in schools. This study has some limitations in that it handles only the organizational learning barriers instead of looking from a broader picture and with regard to the sample as it does not represent the case in Turkey and therefore cannot be reflective in representing the Turkish context in international terms. Kızıldağ, Demirtaş-Zorbaz and Zorbaz (2017) recently 
conducted a study on the correlation of school engagement of high school students with absenteeism, academic achievement, peer relationships and fear of failure gathering data from 515 students in Ankara. The authors used different scales for each dimension and the results indicated that school engagement is predicted significantly by absenteeism and peer relationships. It can be said that this is mainly a correlation study and again is only based on students in Ankara, Nayır (2017) conducted a study on the relationship between class engagement and motivation levels among 500 high school students in Ankara and included 322 of them in the study. The results indicated that students mostly adopted mastery-oriented learning, which was followed by performance-avoidance oriented and performance-approach oriented learning. As mentioned earlier, this study also could not be representative as it focused only on students in Ankara and handled a few aspects of school engagement. Yıldırım (2006) conducted a study on social support and academic achievement with 962 8-1 $11^{\text {th }}$ grade students in Ankara and mentioned that there is a meaningful relationship between social support and students' academic achievement (Yıldırım ve Ergene, 2003; Yıldırım, 1998) and that social support also plays a role in students' continuing and adapting to their school life as well. In his study, Y1ldirım (2006) found out that parental support is a significant indicator of academic achievement, supported by other studies (Lopez, Ehly \& Vazquez, 2002; Yıldırım, 2000). Moreover, students who have problems about their school life, who have a fear about getting low mark or whose teachers are rude or not understanding have a lower academic achievement (Yıldırım, 2006).

Compared with the aforementioned studies conducted in the Turkish context, this present study has some substantial differences. Firstly, this study approached the learning barriers from a broader point of view including emotional and motivational aspects under six headings; self-efficacy, selfregulation, deficiency of professional/parental/sibling support and deficiency of consultancy, learning environment, fear of failure, rejection, criticism and judgment and embarrassment. Secondly, the participants of this study were 2175 high school students selected randomly from the seven regions of Turkey. Thirdly, two cities from each of the seven regions were chosen according to their socioeconomic states, which mean one city had a low while the other had a high socio-economic development levels. Last but not least, the number of participants, the cities selected throughout all the country and the broad framework in which learning barriers were examined could make this study significant in international terms as it provided a fundamental reflection of the Turkish context in terms of learning barriers faced by high school students. Within this framework, this study aims to determine the learning barriers that high school students face in all seven regions of Turkey. In line with the purpose of the study, answers are sought to the following research question:

In what areas do high school students from different regions face learning barriers regarding a) self-efficacy; b) self-regulation; c) deficiency of professional/parental/sibling support and deficiency of consultancy; d) learning environment; e) fear of failure, rejection, criticism and judgment and embarrassment?

\section{Method}

The study employed a descriptive research methodology in order to collect data from all seven regions of Turkey to determine "what is the case?" in terms of the learning barriers of high school students. The purpose of this study is to yield valuable data about opinions, attitudes and practices (Gall \& Gall 2003) of high school students by using six different scales developed by Gürlen and Cihan (2016).

\section{Participants}

The participants of the study are 2175 students attending high schools located in Turkey. Stratified random sampling was used to determine the sample of the study (Fraenkel, Wallen\& Hyun 2012). The following steps were taken during the sampling process:

(i) The target (and accessible) population was identified as the ninth, tenth and eleventh-grade high school students,

(ii) The State Planning Organization in Turkey periodically conducts a study on the socioeconomic development index in the country by provinces. In the SEGE-2011 study, 61 indicators were used under eight variables for 81 provinces in seven regions (Ministry of Development, 2013). The ten provinces having the highest socio-economic status according to SEGE-2011 study are 
located in the Marmara, Aegean, Central Anatolia and Mediterranean Regions of Turkey. In this study, the learning barrier scales were conducted in two cities in each region and the cities were selected according to their socio-economic development levels, namely, one from the highest and one from the lowest level. In some regions, like the Marmara Region, almost all cities have a high socioeconomical level. In such cases, two cities were randomly selected. If the cities had all been selected from low or high levels, the results might have been distorted since, for instance, the available opportunities would differ substantially in these cities. The distribution of the sample group with regard to the cities and regions is shown in Table 1.

\section{Table 1}

Participants with regard to Regions and Cities

\begin{tabular}{|c|c|c|c|}
\hline Region & City & Students & Total \\
\hline \multirow{2}{*}{ MA } & Balıkesir & 91 & \multirow{2}{*}{194} \\
\hline & Kocaeli & 103 & \\
\hline \multirow{2}{*}{ BS } & Zonguldak & 235 & \multirow{2}{*}{413} \\
\hline & Artvin & 178 & \\
\hline \multirow{2}{*}{ EA } & Malatya & 105 & \multirow{2}{*}{306} \\
\hline & Erzincan & 201 & \\
\hline \multirow{2}{*}{ SEA } & Şanlıurfa & 230 & \multirow{2}{*}{384} \\
\hline & Adiyaman & 154 & \\
\hline \multirow{2}{*}{ M } & Antalya & 122 & \multirow{2}{*}{264} \\
\hline & Kahramanmaraş & 142 & \\
\hline \multirow{2}{*}{$\mathrm{CA}$} & Konya & 154 & \multirow{2}{*}{313} \\
\hline & Aksaray & 159 & \\
\hline \multirow{2}{*}{ A } & İzmir & 201 & \multirow{2}{*}{301} \\
\hline & Kütahya & 100 & \\
\hline Total & & & 2175 \\
\hline
\end{tabular}

Note: $\mathrm{MA}=$ Marmara. $\mathrm{BS}=$ Black Sea. EA=Eastern Anatolia. SEA=Southeastern Anatolia. $\mathrm{M}=$ Mediterranean. $\mathrm{CA}=$ Central Anatolia. $\mathrm{A}=$ Aegean.

As for demographic information of the participants, $68.9 \%$ of 2175 students are female. Mean value for the ages of students was found to be 16. In terms of the education level of their mothers, $56.8 \%$ are graduates of primary school, $21.3 \%$ are graduates of middle school, $16.5 \%$ are graduates of high school, $3.2 \%$ are graduates of university and $1.0 \%$ of their mothers are postgraduates. In addition, $35.9 \%$ of their fathers are graduates of primary school, $27.9 \%$ are graduates of middle school, $27.0 \%$ are graduates of high school, and 5.7\% are graduates of university and lastly, $3.2 \%$ are postgraduates.

\section{Data Collection Tools}

The scales named self-efficacy, the self-regulation, deficiency of professional/parental/sibling support and consultancy, the learning environment scale, the fear of failure, rejection, criticism and judgment and the embarrassment, developed by Gürlen\&Cihan (2016), were used in this study. These scales, which have 5-point Likert scale from Absolutely Agree (4.21 - 5.00) to Absolutely Disagree (1 -1.80 ), have 70 items in total. Cronbach's alpha reliability coefficients of these scales were calculated as $0.76,0.89,0.92,0.76,0.85$, and 0.93 respectively for internal consistency of each scale. For content validity, expert judgments were gathered and the items accepted to be appropriate by all experts were used in the scales.

\section{Data Collection Process and Data Analysis}

The data collection process was between fall and spring term of 2015-2016 academic year. Firstly, permission was gathered from the Ministry of National Education and the Ethical Institution at Hacettepe University. Afterwards, the provincial director of national education was called in each city where the scales would be administered and school directors in related schools were called to get their approval for application of scales. After getting approval, the scales were sent to the practice schools in closed envelopes by post. The students were given 20 minutes to answer the items. The schools sent the scales in closed envelopes back to the researchers. 
Mean values of the items were calculated one by one to examine the learning barriers seen in different regions and Turkey in general.

\section{Results}

The descriptive statistics of the six scales were examined and presented in the following table for the whole participants. According to Table 2, the highest mean is in the deficiency of professional/parental/sibling support and deficiency of consultancy, while the lowest mean is in embarrassment.

\section{Table 2}

Descriptive Statistics

\begin{tabular}{lccccc}
\hline Scales & 1-5 Interval & Mean & SD & Skewness & Kurtosis \\
\hline Self-efficacy & 4,05 & 32,36 & 4,499 & -.713 & 1,063 \\
Self-regulation & 1,68 & 28,62 & 7,654 &,- 468 &,- 368 \\
$\begin{array}{l}\text { Deficiency of } \\
\text { professional/parental/sibling }\end{array}$ & 3,87 & 76,54 & 14,462 &,- 763 &, 543 \\
$\begin{array}{l}\text { support and consultancy } \\
\text { Embarrassment }\end{array}$ & 2,24 & 17,92 & 8,639 &, 695 &,- 373 \\
$\begin{array}{l}\text { Learning environment } \\
\text { Fear of failure, rejection, }\end{array}$ & 4,03 & 36,28 & 5,625 &,- 787 &, 808 \\
criticism and judgment & 3,58 & 28,62 & 7,654 &,- 468 &,- 368 \\
\hline
\end{tabular}

Accordingly, the sample mean is higher for the deficiency of professional/parental/sibling support and deficiency of consultancy $(M=76.54, S D=14.462)$ than learning environment $(M=36.28$, $S D=5.625)$, self-efficacy $(M=32.36, S D=4.499)$, fear of failure, rejection, criticism and judgment $(M=28.62, S D=7.654)$ and self-regulation $(M=28.62, S D=7.654)$, while the lowest mean value belongs to embarrassment $(M=17.92, S D=8.639)$.

As the items of the self-efficacy, self-regulation, deficiency of professional/parental/sibling support and deficiency of consultancy and learning environment scales included items with positive meanings; the items with the lowest percentage were taken into consideration in indicating the learning barriers observed in these areas. In contrast, the items in the fear of failure, rejection, criticism and judgment, and embarrassment scales included items with negative meanings. Therefore, the items with the highest percentage were interpreted as they showed the learning barriers observed in these two areas. Furthermore, to determine the high and low percentages, the mean values of each sub-scale were divided in the number of items in each scale and an interval value was found between 1 and 5 for each scale.

\section{Learning Barriers with regard to Self-Efficacy}

When the mean values of the items regarding self-efficacy were examined, it was seen that the lowest values, although still high, were among items 1, 2 and 6 as can be seen in Table 3 .

Table 3

Highest Mean Values in the Self-Efficacy Scale with Regard to the Regions

\begin{tabular}{|c|c|c|c|c|c|c|c|}
\hline \multirow{2}{*}{ Items } & \multicolumn{7}{|c|}{ Mean Regions } \\
\hline & $\mathrm{CA}$ & BS & MA & A & M & EA & SA \\
\hline 1. I can learn my school subjects easily. & 3.91 & 3.88 & 3.86 & & 3.73 & & \\
\hline $\begin{array}{l}\text { 2. I can ask my teacher for help when I have a difficulty } \\
\text { about my school subjects. }\end{array}$ & 3.91 & & & 3.81 & & & 3.71 \\
\hline 6. My teachers think that I am a responsible student. & & 3.89 & & & & 3.87 & \\
\hline
\end{tabular}

Accordingly, in the CA Region, students a bit suffer from learning their school subjects easily $(M=3.91)$ and asking their teachers for help when they have a difficulty about their school subjects 
$(M=3.91)$. In the BS Region, students a bit suffer from learning their school subjects easily $(M=3.88)$ and most of them do not believe they are responsible students in their teachers' eyes $(M=3.89)$. Likely, in the MA Region, students somewhat suffer from learning their school subjects easily $(M=3.86)$. In the A Region, it was found that students have difficulty in asking their teachers for help when they have a difficulty about their school subjects $(M=3.81)$. In the $M$ Region, students have difficulty in learning their school subjects easily $(M=3.73)$. As for the EA Region, most students do not believe they are responsible students in their teachers' eyes $(M=3.87)$. In the Southeastern Region, it seemed to be difficult for students to ask their teachers for help when they have a difficulty about their school subjects $(M=3.71)$.

\section{Learning Barriers with regard to Self-Regulation}

When the mean values of the items regarding self-regulation were examined, in Table 4, it was seen that the lowest values were among items 11 and 18 for all regions, except for the A where only item 18 had the mean value.

\section{Table 4}

Highest Mean Values in the Self-Regulation Scale with Regard to the Regions

\begin{tabular}{|c|c|c|c|c|c|c|c|}
\hline \multirow[t]{2}{*}{ Items } & \multicolumn{7}{|c|}{ Mean Regions } \\
\hline & $\mathrm{CA}$ & $\mathrm{BS}$ & MA & A & $\mathrm{M}$ & EA & SA \\
\hline 11. I prepare a study schedule for myself. & 3.05 & 3.02 & 3.08 & & 3.11 & 2.92 & 3.15 \\
\hline $\begin{array}{l}\text { 18. I can focus on studying even when something attracts my } \\
\text { attention. }\end{array}$ & 3.07 & 3.12 & 3.19 & 2.84 & 3.09 & 3.17 & 3.18 \\
\hline
\end{tabular}

Students in all regions except for the A are indecisive or do not prepare a study schedule for themselves $(M=3.05$ for the CA Region, $M=3.02$ for the BS Region, $M=3.08$ for the MA Region, $M=3.11$ for the M Region, $M=2.92$ for the EA Region, $M=3.15$ for the SEA Region). Furthermore, it was found that students in all regions find it difficult to focus on studying even when something distracts their attention ( $M=3.07$ for the CA Region, $M=3.12$ for the BS Region, $M=3.19$ for the MA Region, $M=2.84$ for the A Region, $M=3.09$ for the M Region, $M=3.17$ for the EA Region, $M=3.18$ for the SEA Region).

\section{Learning Barriers with regard to the Deficiency in Professional/Parental/Sibling Support and Consultancy}

The mean values regarding the deficiency in professional/parental/sibling support and consultancy showed that the lowest values were among items 27, 39 and 40 for almost all regions, except for the M Region where the lowest mean values were on items 27 and 39, as can be seen in Table 5 .

\section{Table 5}

Highest Mean Values in the Deficiency in Professional/Parental/Sibling Support and Consultancy Scale with regard to the Regions

\begin{tabular}{lccccccc}
\hline \multicolumn{1}{c}{ Items } & \multicolumn{9}{c}{ Mean Regions } & & \\
& CA & BS & MA & A & M & EA & SA \\
\hline $\begin{array}{l}\text { 27. My parent helps me do my homework. } \\
\text { 39. My teachers have a great role in my willingness to come } \\
\text { to school. }\end{array}$ & 3.25 & 3.20 & 3.29 & 3.27 & 3.19 & 3.17 & 3.07 \\
$\begin{array}{l}\text { 40. My teachers are closely interested in my school } \\
\text { achievementstudent. }\end{array}$ & 3.35 & 3.37 & 3.34 & 2.69 & 3.64 & 3.61 & 3.49 \\
\hline
\end{tabular}

Accordingly, students in all regions are indecisive or do not think that their parent helps them do their homework ( $M=3.25$ for the CA Region, $M=3.20$ for the BS Region, $M=3.29$ for the MA Region, $M=3.27$ for the A Region, $M=3.19$ for the M Region, $M=3.17$ for the EA Region, $M=3.07$ for the SEA Region). Additionally, students in regions except EA and SEA do not believe their teachers have a great role in their willingness to come to school ( $M=3.46$ for the CA Region, $M=3.37$ for the BS 
Region, $M=3.34$ for the MA Region, $M=2.94$ for the A Region, $M=3.64$ for the M Region). In fact, the mean values for this item were still low for the EA Region $(M=3.61)$ and for the SEA Region $(M=3.49)$; however, there were items with lower percentages than these with regard to the deficiency of professional/parental/sibling support and consultancy in these regions. Moreover, students in all regions except for the $\mathrm{M}$ Region are indecisive or do not think that their teachers are closely interested in their school achievement ( $M=3.35$ for the CA Region, $M=3.32$ for the BS Region, $M=3.30$ for the MA Region, $M=2.94$ for the A Region, $M=3.39$ for the EA Region, $M=3.29$ for the SEA Region).

\section{Learning Barriers with regard to the Learning Environment}

The learning barriers regarding the learning environment were all the same for the seven regions, where the lowest mean values were observed among items 50 and 52, as seen in Table 6 .

\section{Table 6}

Highest Mean Values in the Learning Environment Scale with regard to the Regions

\begin{tabular}{|c|c|c|c|c|c|c|c|}
\hline \multirow[t]{2}{*}{ Items } & \multicolumn{7}{|c|}{ Mean Regions } \\
\hline & $\mathrm{CA}$ & BS & MA & A & M & EA & SA \\
\hline $\begin{array}{l}\text { 50. The learning environment in the classroom motivates me } \\
\text { to learn. }\end{array}$ & 3.63 & 3.51 & 3.38 & 3.12 & 3.64 & 3.49 & 3.38 \\
\hline $\begin{array}{l}\text { 52. While I am studying, I put away the things (e.g. telephone, } \\
\text { television, etc.) that will distract me. }\end{array}$ & 3.20 & 3.40 & 3.22 & 2.84 & 3.50 & 3.43 & 3.53 \\
\hline
\end{tabular}

The students in all regions are indecisive or do not believe that the learning environment in the classroom motivate them to learn ( $M=3.63$ for the CA Region, $M=3.51$ for the BS Region, $M=3.38$ for the MA Region, $M=3.12$ for the A Region, $M=3.64$ for the M Region, $M=3.49$ for the EA Region, $M=3.38$ for the SEA Region). What's more, it was found that most students do not put away the things (e.g. telephone, television, food, etc.) that will distract them while studying ( $M=3.20$ for the CA Region, $M=3.40$ for the BS Region, $M=3.22$ for the MA Region, $M=2.84$ for the A Region, $M=3.50$ for the M Region, $M=3.43$ for the EA Region, $M=3.53$ for the SEA Region).

\section{Learning Barriers with regard to Fear of Failure, Rejection, Criticism and Judgment}

When the mean values of the items regarding fear of failure, rejection, criticism and judgmentwere examined for the seven regions, as seen in Table 7, it was seen that the highest mean values, were among items 55 and 57.

\section{Table 7}

Highest Mean Values in the Fear of Failure, Rejection, Criticism and Judgment Scale with Regard to the Regions

\begin{tabular}{lccccccc}
\hline \multicolumn{1}{c}{ Items } & \multicolumn{4}{c}{ Mean Regions } & \multicolumn{1}{c}{ EA } & SA \\
& CA & BS & MA & A & M & EA \\
& 4.01 & 3.89 & 4.11 & 3.77 & 4.11 & 3.86 & 4.09 \\
55. I feel nervous before exams & 3.93 & 3.87 & 4.07 & 3.84 & 4.03 & 3.78 & 4.05 \\
57. It is important to me not to be excluded by my friends. & 3.93 \\
\hline
\end{tabular}

According to Table 7, students in all regions mention that they feel nervous before exams ( $M=4.01$ for the CA Region, $M=3.89$ for the BS Region, $M=4.11$ for the MA Region, $M=3.77$ for the A Region, $M=4.11$ for the $M$ Region, $M=3.86$ for the EA Region, $M=4.09$ for the SEA Region). Likewise, students in all regions believe that it is important for them not to be excluded by their friends ( $M=3.93$ for the CA Region, $M=3.87$ for the BS Region, $M=4.07$ for the MA Region, $M=3.84$ for the A Region, $M=4.03$ for the M Region, $M=3.78$ for the EA Region, $M=4.05$ for the SEA Region).

\section{Learning Barriers with regard to Embarrassment}

When the mean values of the items regarding embarrassment were examined for the regions, as can be seen in Table 8, it was seen that the highest mean values were on item 68 for all regions and both 67 and 68 for the MA Region and EA Region. 


\section{Table 8}

Highest Mean Values in the Embarrassment Scale with regard to the Regions

\begin{tabular}{|c|c|c|c|c|c|c|c|}
\hline \multirow[t]{2}{*}{ Items } & \multicolumn{7}{|c|}{ Mean Regions } \\
\hline & CA & BS & MA & A & M & EA & $\mathrm{SA}$ \\
\hline $\begin{array}{l}\text { 67. I think I look weird when I get a promise to spea } \\
\text { 68. I feel anxious when I am in a social environmen }\end{array}$ & 2.60 & 2.36 & $\begin{array}{l}2.30 \\
2.29\end{array}$ & 2.15 & 2.62 & $\begin{array}{l}2.40 \\
2.39\end{array}$ & 2.63 \\
\hline
\end{tabular}

However, the analysis in this scale showed that even the highest percentages were around 2.50, which might show that most of the students in Turkey do not suffer from embarrassment as a learning barrier. Nevertheless, the mean values for item 67 "I think I look weird when I get a promise to speak in class." were $M=2.30$ for the MA Region and $M=2.40$ for the EA Region. Moreover, the mean values for item 68 "I feel anxious when I am in a social environment." were $M=2.60$ for the CA Region, $M=2.36$ for the BS Region, $M=2.29$ for the MA Region, $M=2.15$ for the A Region, $M=2.62$ for the M Region, $M=2.39$ for the EA Region, $M=2.63$ for the SEA Region.

\section{Discussion, Conclusion and Recommendations}

This study aimed to reveal and examine learning barriers of high school students as such barriers can affect the validity and reliability of all kinds of measurements conducted with regard to students. Therefore, describing them may contribute to the guide the measurement results gathered from students. With regard to the learning barriers stemming from self-efficacy issues, students in four out of seven regions mentioned they could not learn their school subjects easily. Furthermore, students in seven regions stated they did not or partly prepare a study schedule for themselves and that they could hardly focus on studying when something attracted their attention, which indicated learning barriers stemming from self-regulation issues. In terms of the learning barriers based on a deficiency in professional/parental/sibling support and consultancy, students in all regions had some negative opinions about the fact that their parents helped them do their homework or whether their teachers had a great role in their willingness to come to school. Additionally, students in all regions but one mentioned their teachers were closely interested in their school achievement. As for learning barriers stemming from the learning environment, all students had some doubts whether the learning environment in the classroom motivated them to learn or whether they out away distractors while they were studying. Moreover, students in all regions mentioned they felt nervous before exams and that it was important not be excluded by their friends in a way to express learning barriers with regard to fear of failure, rejection, criticism and judgment. Lastly, in terms of embarrassment issues, students in all regions mentioned they felt anxious when they were in a social environment, which indicated a learning barrier (for all scales, see Appendix 1).

The results of the study suggest that students have some difficulty in planning how to study, which is a self-regulative skill. Pintrich and Garcia (1991) found that students setting goals, planning effectively and monitoring their goal progress are more likely to achieve higher on knowledge tests than students who fail to engage in these activities. However, this might be related with another finding of this study. The participants of this study were mostly unsure whether their teachers have a great role in their willingness to come to school and if teachers are interested in their school achievement. This indicates the existence of a learning barrier regarding teacher support. Likewise, Turhan, Karabatak and Polat (2014) also found that teachers were insensitive to problems in schools and tended to accuse students in case of failure. This finding is supported with the view of Weinstein and Mayer, who mentioned that "good teaching teaches students how to learn, how to remember, how to think, and how to motivate themselves" (1986: 315), which are closely related with self-regulative skills. From a similar point of view and in a way underlining the close relationship between selfregulated learning and teacher support, Patrick, Ryan and Kaplan (2007), in their study with fifth grade students, found that task engagement and the use of self-regulated learning strategies was more prevalent in students who received regular support from their teacher and peers. In a similar vein, relatedness, which is a sense of being close to students through a sense of warmth, affection, and acceptance of students on the teacher's side, turned out to be positive contributors to students' learning and well-being (Furrer \& Skinner, 2003). Students feel they belong in school when their 
teachers express involvement and warmth towards them (Martin \& Dowson, 2009; Wentzel, 1997) in a way treating students with care and affection and making students feel they enjoy having them in class. Therefore, when teachers are reliable sources of emotional and instrumental support especially in difficult times, students feel connected to their teachers and safe at school (as cited by Furrer, Skinner \& Pitzer, 2014), which promotes school engagement. These results show that teacher support, whose deficiency can make strong learning barriers on the side of students, is very important in both creating self-regulated learners and school engagement.

The results of this study indicated that students received little or no help from their parents with regard to their homework, which might be related to parental support on schoolwork. Research shows that parents are able to influence the academic and psychosocial development in children and adolescents (e.g., Yıldırım, 2006; Yıldırım, 2000; Abar, Carter \& Winsler, 2009; Purdie, Carroll, \& Roche, 2004). Accordingly, strong parental involvement, in the way perceived by the adolescent, was found to be an important influence on adolescents' self-regulatory behaviors (Purdie, Carroll, \& Roche, 2004). This is supported by the study of Henderson \& Berla, (1994), as it was found that schools supporting significant parent involvement have higher levels of student achievement, increased school attendance, higher graduation rates, larger enrollment in post-secondary education and students with positive attitudes about school.

According to the results of the study, similar results were obtained with regard to the selfefficacy perception of students. Most of the 2175 high school students mentioned they could not learn school courses well, had difficulty in school work and most importantly, could not ask for help from their teachers, highlighting the learning barrier regarding teacher support. These three main reasons about self-efficacy perception were identified as barriers making a negative effect on students' learning. Furthermore, it was found that the learning environment in classrooms did not motivate students to learn. This seems to be in relation with what Zimmerman (2001) mentioned about selfefficacy beliefs that such beliefs show convergent validity in affecting such key determiners of academic motivation as choice of activities, level of effort, persistence, and emotional reactions.

The results of the study suggest that students should be supported to get motivated for learning by letting them learn by doing and experiencing as well as building an effective communication between students and students, and teachers and students. As Martin and Dowson (2009) mentioned, students who have enough opportunities to communicate with each other, are given emotional support and share learning experiences with their peers, are more likely to feel that can be understood and cared for by their peers. Similarly, Yıldırım (2006) found out that peer support was an important indicator of academic success. It is important that classrooms are not crowded since the number of students and classroom layout directly affect interaction during classes. Organizing an effective learning environment can help students to develop their self-regulation skills, increase their awareness and so improve their self-confidence; in other words, this may give them a chance to develop their self-efficacy beliefs in a positive way. Zimmerman (2000) supports this by saying that self-efficacy beliefs provide students with a sense of agency to motivate their own learning by the use of selfregulatory processes such as goal setting, self-monitoring, self-evaluation, and strategy use. In a similar vein, there is evidence that the use of self-regulation strategies can lead to increases in selfefficacy beliefs and academic achievement (Schunk, 1984; Zimmerman \& Martinez-Pons, 1990).

The results of the study show that students' effective learning and academic achievement are closely related to their motivation for learning through developing positive emotions towards their teachers and enjoying learning. Curriculum in general and syllabi in particular always play inevitable roles in the entire process of learning in an educational system. Therefore, the teaching/learning material (courses) may be properly designed in accordance with the social need and national demand (Khan 2011). Thus, affective learning may be held as carefully as cognitive learning in high school curricula as some problems occur in realizing cognitive learning when the affective domain is ignored. As Khan (2011) stated it seems imperative for policy makers, planners, curriculum designers, pedagogues and administrators to take learning barriers into considerations so through a proper diagnosis of the barriers, these can be minimized or removed if possible. 


\section{References}

Abar, B., Carter, K. L., \& Winsler, A. (2009). The effects of maternal parenting style and religious commitment on self-regulation, academic achievement, and risk behavior among AfricanAmerican parochial college students. Journal of Adolescence, 32(2), 259-273.

Adelman, H. S. \& Taylor, L. (2008). Rebuilding for learning, addressing barriers to learning and teaching, and re-engaging students. USA; Scholastic Inc.

Arroyo, A. A., Rhoad, R., \& Drew, P. (1999). Meeting diverse student needs in urban schools: Research-based recommendations for school personnel. Preventing School Failure, 43, 145-153.

Dennis, S. L. \& Osterholt, D. A. (2011). Holistic support that promotes student learning. The New England of Higher Education New England Board of Education. Retrieved from www.nebhe.org/thejournal/holistic-support-that-promotes-student-learning/

Department of Education (1997). Quality education for all: overcoming barriers to learning and development. Report of the NCSNET \& NCESS. Pretoria: Government Printer.

Endler, A., Rey, G. D., \& Butz, M. V. (2012). Towards motivation- based adaptation of difficulty in elearning programs. Australasian Journal of Educational Technology, 28, 1119-1135.

Fuller, M.L. \& Olsen, G. (1988). Home-school relations. Boston, MA: Allyn and Bacon.

Furrer, C., \& Skinner, E. A. (2003). Sense of relatedness as a factor in children's academic engagement and performance. Journal of Educational Psychology, 95, 148 -162.

Furrer, C. J., Skinner, E. A. \& Pitzer, J. R. (2014). The influence of teacher and peer relationships on students' classroom engagement and everyday motivational resilience. National Society for the Study of Education, 113(1), 101-123.

Gürlen, E. \& Cihan, T. (2016). Barriers to Effective Learning of High School Students in Turkey. International Journal of Assessment Tools in Education. 3 (2), 161-173.

Henderson, A., \& Berla, N. (Eds.). (1994). A new generation of evidence: The family is critical to student achievement. Washington, DC: National Committee for Citizens in Education, Center for Law and Education.

Khan, I. A. (2011). An analysis of learning barriers: The Saudi Arabian context. International Education Studies. 4(1), 242-247.

Kızıldağ, S., Demirtaş-Zorbaz, S. \& Zorbaz, O. (2017). School engagement of high school students. Education and Science, 42(189), 107-119.

López, G. (2001). The value of hard work: Lessons on parent involvement from an (im)migrant household. Harvard Education Review, 71(3), 416-437.

Lopez, E. Ehly, S., \& Vazquez, E. G. (2002). Acculturation, social support and academic achievement of Mexican and Mexican American high school students: An exploratory study. Psychology in the Schools, 39 (3), 245-257.

Martin, A. J., \& Dowson, M. (2009). Interpersonal relationships, motivation, engagement, and achievement: yields for theory, current issues, and educational practice. Review of Educational Research, 79, 327-365.

Nayir, F. (2017). The relationship between student motivation and class engagement levels. Eurasian Journal of Educational Research, 71, 59-78.

OECD (2003). Student engagement in school: a sense of belonging and participation. Results from PISA 2000. OECD, Paris.

Patrick, H., Ryan, A.M., \& Kaplan, A. (2007). Early adolescents' perceptions of the classroom social environment, motivational beliefs, and engagement. Journal of Educational Psychology, 99(1), 83-98. 
Pintrich, P. R. \& Garcia, T. (1994). Student goal orientation and self-regulation in the college classroom, in M. L. Maehr \& P. R. Pintrich (eds) Advances in motivation and achievement: Goals and self-regulatory processes, pp. 371-402. Greenwich, CT: JAI Press.

Preacher, K. J. \& MacCallum R. C. (2003). Repairing Tom Swift's electric factor analysis machine. Understanding Statistics. 2(1), 13-43.

Schunk, D. H. (1984). Self-efficacy perspective on achievement behavior. Educational Psychologist, $19,48-56$.

T.C. Kalkınma Bakanlığı, İllerin ve Bölgelerin Sosyo-ekonomik Gelişmişlik Sıralaması Araştırması (SEGE, 2011). Retrieved from http://www.kalkinma.gov.tr/ Pages/content.aspx?1=7a0b8e4add0f-43b1-880c-e682b9d15cc3\&i=548

Turhan, M., Karabatak, S. \& Polat, M. (2014). The investigation of the organizational learning barriers in schools using vignette technique. Mersin University Journal of the Faculty of Education, 10(1), 66-83.

Yıldırım, İ. (1998). Akademik başarı düzeyleri farklı olan lise öğencilerinin sosyal destek düzeyleri. Psikolojik Danışma ve Rehberlik Dergisi, 2 (9), 33-38.

Yıldırım, İ. (2000). Akademik başannın yordayıcısı olarak sınav kaygısı ve sosyal destek. Hacettepe Eğitim Fakültesi Dergisi, 18, 167-176.

Yıldırım, İ. \&. Ergene, T. (2003). Lise son sınıf öğrencilerinin akademik başarılarnın yordayıcısı olarak sınav kaygısı, boyun eğici davranışlar ve sosyal destek. Hacettepe Eğitim Fakültesi Dergisi, 25,224-234.

Yıldırım, İ. (2006). Daily hassles and social support as predictors of academic achievement. H. Eğitim Fakültesi Dergisi (H.U. Journal of Education). 30, 258-267.

Young, S. H., \& Vrongistinos, K. (2002). In-service teachers' self-regulated learning strategies related to their academic achievement. Journal of Instructional Psychology, 29(3), 147-154.

Webb, M. A., Stewart, D., Bunting, L. \& Regan, H. (2012). Breaking down barriers to learning: Primary school-based counselling and support. No.14. Policy and Practice Briefing. Retrieved from http://www.barnardos.org.uk/ 14246_pp_briefing_14_breaking_down_barriers.pdf

Weiqiao Fan, Li-Fang Zhang. (2009). Are achievement motivation and thinking styles related? A visit among Chinese university students. Learning and Individual Differences, 19(2), 299-303.

Weinstein, C. E . \& Mayer, R. (1986). The teaching of learning strategies, in M. Wittrock (ed.) Handbook of research on teaching, 315-327. New York: Macmillan.

Zimmerman, B. J. (1986). Development of self-regulated learning: Which are the key subprocesses? Contemporary Educational Psychology, 16, 307-313.

Zimmerman, B. J., \& Martinez-Pons, M. (1990). Student differences in self-regulated learning: Relating grade, sex, and giftedness to self-efficacy and strategy use. Journal of Educational Psychology, 82, 51-59.

Zimmerman, B. J. (2000). Self-Efficacy: an essential motive to learn. Contemporary Educational Psychology 25, 82-91. 


\section{Appendix I}

\section{LEARNING BARRIERS SCALE}

\section{Dear participant,}

This study is being conducted to determine the factors than hinder your school achievement. You do not have to write your name and surname since the answers gathered will be used in scientific studies. The fact that you give sincere answers to the questions reflecting your real feelings is significant to the results of the study.

Thank you for your participation in the study.

\section{PERSONAL INFORMATION}

1. Age

2. Gender

3. Hometown :

1. ( ) Central Anatolian Region

2. ( ) Black Sea Region

3. ( ) Marmara Region

4. ( ) Aegean Region

5. ( ) Mediterranean Region

6. ( ) Eastern Anatolia Region

7. ( ) Southeastern Anatolia Region

4. School $\quad$ : High School - Anatolian High School - Vocational High School

5. Grade Level : 9th Grade - 10th Grade - 11th Grade - 12th Grade

6. Mother's Level of Education: Primary School - Secondary School - High School Undergraduate - Graduate

7. Father's Level of Education: Primary School - Secondary School - High School - Undergraduate - Graduate

8. Number of Siblings :

\begin{tabular}{|c|c|c|c|c|c|c|}
\hline & $\underline{\text { Self efficacy }}$ & 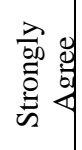 & $\underset{\mathscr{E}}{\stackrel{E}{4}}$ & $\begin{array}{l}\vec{d} \\
\vec{d} \\
\bar{d} \\
\vec{d} \\
\bar{b}\end{array}$ & 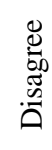 & 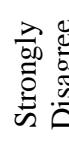 \\
\hline 1 & I can learn my school subjects easily. & & & & & \\
\hline 2 & $\begin{array}{l}\text { I can ask my teacher for help when I have a difficulty about my school } \\
\text { subjects. }\end{array}$ & & & & & \\
\hline 3 & $\begin{array}{l}\text { I can ask my friends for help when I have a difficulty about my school } \\
\text { subjects. }\end{array}$ & & & & & \\
\hline 4 & I am good at learning. & & & & & \\
\hline 5 & I get good grades in exams when I study. & & & & & \\
\hline 6 & My teachers think that I am a responsible student. & & & & & \\
\hline 7 & I am willing to learn. & & & & & \\
\hline 8 & I trust myself about being successful at school. & & & & & \\
\hline
\end{tabular}




\begin{tabular}{|c|c|c|c|c|c|c|}
\hline & $\underline{\text { Self regulation }}$ & 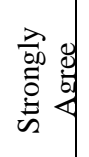 & 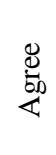 & $\begin{array}{l}\vec{d} \\
\frac{0}{0} \\
\frac{d}{0} \\
\vdots \\
0\end{array}$ & 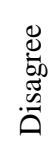 & 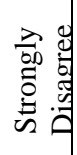 \\
\hline 9 & I do my homework on time. & & & & & \\
\hline 10 & I complete the tasks given by my teacher about school subjects on time. & & & & & \\
\hline 11 & I prepare a study schedule for myself. & & & & & \\
\hline 12 & I am a responsible student. & & & & & \\
\hline 13 & Being successful at school is important to me. & & & & & \\
\hline 14 & I go on studying even when I fail. & & & & & \\
\hline 15 & I follow my progress in my school subjects. & & & & & \\
\hline 16 & I try different study methods when I fail. & & & & & \\
\hline 17 & I do my homework on time. & & & & & \\
\hline 18 & I can focus on studying even when something attracts my attention. & & & & & \\
\hline 19 & I know how to study social school subjects. & & & & & \\
\hline 20 & I know how to study scientific school subjects. & & & & & \\
\hline 21 & I listen to my teacher attentively in class. & & & & & \\
\hline 22 & I aim to learn as much as possible at school. & & & & & \\
\hline 23 & I set goals for myself to be successful at school subjects. & & & & & \\
\hline 24 & I aim to be successful in school subjects. & & & & & \\
\hline \multirow[t]{2}{*}{25} & I ask for help when I have a difficulty about my school subjects. & & & & & \\
\hline & $\begin{array}{l}\text { Deficiency of professional/parental/sibling support and deficiency of } \\
\text { consultancy }\end{array}$ & 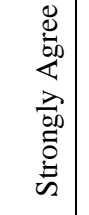 & $\stackrel{\bigotimes}{\circlearrowright}$ & 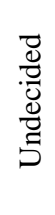 & 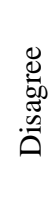 & 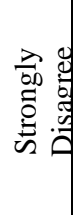 \\
\hline 26 & My parent helps me learn my school subjects. & & & & & \\
\hline 27 & My parent helps me do my homework. & & & & & \\
\hline 28 & My parent helps me value and care about school. & & & & & \\
\hline 29 & My parent is pleased with my school achievement. & & & & & \\
\hline 30 & My parent thinks that I am a responsible student. & & & & & \\
\hline 31 & My parent trusts me to be successful in my school subjects. & & & & & \\
\hline 32 & My parent encourages me to be successful in school subjects. & & & & & \\
\hline 33 & My parent appreciates my achievement. & & & & & \\
\hline 34 & My parent is closely interested in my school achievement. & & & & & \\
\hline 35 & My teachers encourage me to be successful. & & & & & \\
\hline 36 & My teachers appreciate my achievement. & & & & & \\
\hline 37 & My teachers trust me to be successful in my school subjects. & & & & & \\
\hline 38 & My teachers encourage me to be successful in school subjects. & & & & & \\
\hline 39 & My teachers have a great role in my willingness to come to school. & & & & & \\
\hline 40 & My teachers are closely interested in my school achievement. & & & & & \\
\hline 41 & $\begin{array}{l}\text { The consultancy teacher helps me if I need help in using effective study } \\
\text { techniques. }\end{array}$ & & & & & \\
\hline 42 & Members of my family help me with my homework. & & & & & \\
\hline 43 & Members of my family help me study. & & & & & \\
\hline 44 & Members of my family encourage me to be successful in school subjects. & & & & & \\
\hline \multirow[t]{2}{*}{45} & Members of my family are closely interested in my school life. & & & & & \\
\hline & $\underline{\text { Learning Environment }}$ & 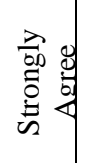 & 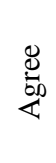 & 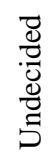 & $\begin{array}{l}\stackrel{\Xi}{0} \\
\stackrel{0}{0} \\
\tilde{\Xi} \\
\stackrel{0}{0}\end{array}$ & 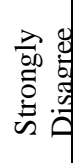 \\
\hline 46 & I build a positive communication with my teachers. & & & & & \\
\hline 47 & I build a positive communication with my friends. & & & & & \\
\hline 48 & I build a positive communication with my parent. & & & & & \\
\hline 49 & I have a positive communication with members of my family. & & & & & \\
\hline
\end{tabular}




\begin{tabular}{|c|c|c|c|c|c|c|}
\hline $\mathbf{5 0}$ & The learning environment in the classroom motivates me to learn. & & & & & \\
\hline 51 & I always study in a definite place at home. & & & & & \\
\hline 52 & $\begin{array}{l}\text { While I am studying, I put away the things (e.g. telephone, television, food, } \\
\text { etc.) that will distract me. }\end{array}$ & & & & & \\
\hline 53 & At home, I have the study environment that I exactly want. & & & & & \\
\hline \multirow[t]{2}{*}{54} & I want my study environment to be quiet. & & & & & \\
\hline & Fear of failure, rejection, criticism and judgment & 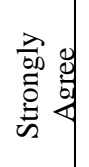 & 总 & 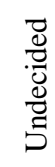 & 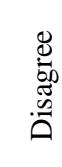 & 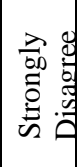 \\
\hline 55 & I feel nervous before exams. & & & & & \\
\hline 56 & I feel discouraged when I get lower grades than my friends in exams. & & & & & \\
\hline 57 & It is important to me not to be excluded by my friends. & & & & & \\
\hline 58 & I feel discouraged when my teachers criticize me about my school subjects. & & & & & \\
\hline 59 & I feel discouraged when my friends criticize me about my school subjects. & & & & & \\
\hline 60 & What my friends think about me is important to me. & & & & & \\
\hline 61 & I shy away from being teased by my friends. & & & & & \\
\hline \multirow[t]{2}{*}{62} & I shy away from being criticized by my parent about my school subjects. & & & & & \\
\hline & Embarrassment & 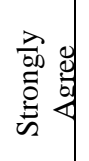 & $\underset{\circlearrowright}{\stackrel{0}{0}}$ & $\begin{array}{l}\overrightarrow{0} \\
\frac{\overrightarrow{0}}{0} \\
\frac{8}{0} \\
5\end{array}$ & 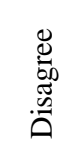 & 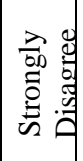 \\
\hline 63 & I am embarrassed to get a promise to speak in class. & & & & & \\
\hline 64 & I have difficulty in expressing myself in front of my classmates. & & & & & \\
\hline 65 & I have difficulty in meeting new people. & & & & & \\
\hline 66 & I cannot find anything to say when I get a promise to speak in class. & & & & & \\
\hline 67 & I think I look weird when I get a promise to speak in class. & & & & & \\
\hline 68 & I feel anxious when I am in a social environment. & & & & & \\
\hline 69 & $\begin{array}{l}\text { I shy away from having eye contact with my teacher when I get a promise to } \\
\text { speak in class. }\end{array}$ & & & & & \\
\hline 70 & $\begin{array}{l}\text { I shy away from having eye contact with my friends when I get a promise to } \\
\text { speak in class. }\end{array}$ & & & & & \\
\hline
\end{tabular}


